\title{
ПРОФЕСІЙНЕ ВИГОРАННЯ МЕДИЧНИХ СЕСТЕР ЯК КОМПОНЕНТ РОБОЧОГО ПРОЦЕСУ
}

\author{
Г. Кравчук ${ }^{1}$, С. Даньчак ${ }^{2}$, О. Прокопчук ${ }^{2}$ \\ 1Заставнівська центральна районна лікарня \\ ${ }^{2}$ Тернопільський національний медичний університет \\ імені І. Я. Горбачевського МОЗ України
}

У статті вивчено та висвітлено феномен емоційного вигорання медичних сестер як компонента рутинної практики, що негативно впливає на здоров’я і ефективність працівників цієї сфери.

\section{PROFESSIONAL BURNOUT OF NURSES AS A COMPONENT OF WORKING PROCESS}

\author{
G. Kravchuk ${ }^{1}$, S. Danchak ${ }^{2}$, O. Prokopchuk ${ }^{2}$ \\ ${ }^{1}$ Zastavniv Central District Hospital \\ ${ }^{2}$ I. Horbachevsky Ternopil National Medical University
} The article studies and highlights the phenomenon of emotional burnout of medical workers, as a component of
routine practice, and same time negatively affects the health and effectiveness of workers in this area.

Вступ. У сучасному світі все більше приділяють увагу проблемам психологічного благополуччя особистості. Центральною складовою роботи медичної сестри є безпосередній контакт, що вимагає постійного психологічного напруження як з пацієнтами, так і з лікарями. Зокрема, потрібно враховувати психічне, моральне та етичне напруження, з якими медсестри стикаються в рутинній практиці щоденно. Окрім того, саме ця категорія медичних працівників стикається 3 найрізноманітнішими проблемами пацієнтів та їхніх родичів, що в результаті зумовлює значне соціальнопсихологічне навантаження. Саме тому дослідження стану психічного та соматичного здоров'я медичних сестер дасть змогу вивчити ті чинники, котрі при постійній персистенції призводять до погіршення якості їхньої роботи та пришвидшують професійне вигорання.

Основна частина. Синдром емоційного вигорання наразі $\epsilon$ достатньо поширеною реакцією організму у відповідь на тривалий вплив стресових чинників, що проявляється емоційним, розумовим та фізичним виснаженням. Найчастіше людина зі синдромом емоційного вигорання починає «вмикати» власні емоції у

(c) Г. Кравчук, С. Даньчак, О. Прокопчук, 2020 відповідь на психотравмувальні впливи чи чинники, причому ці дії призводять до погіршення власної професійної діяльності [6].

Історія терміну «синдром емоційного вигорання» (staff burnout syndrome) починається з 1974 р., коли американський психіатр Н. J. Freundenberger вперше звернув увагу на цей феномен у працівників психіатричної сфери і описав його як «поразку, виснаження або зношення, що відбувається з людиною внаслідок різко завищених вимог до власних ресурсів і сил» [1].

у 1977 р. на щорічній конференції Американської психологічної асоціації термін «синдром емоційного вигорання» увійшов до наукового лексикону. 3'явилося багато публікацій і досліджень стосовно проблеми емоційного вигорання серед медичних працівників. Дослідження в різних країнах світу доводять, що синдром емоційного вигорання починає формуватися уже в студентів-медиків старших курсів. Робота в медичній сфері становить перед людиною багато різних, а часто і надмірних вимог $[12,16]$. Для повсякденної діяльності медичних працівників характерним є високий рівень стресу, який вони відчувають доволі часто [13]. 
Всесвітня організація охорони здоров'я (ВООЗ) визнала, що синдром емоційного вигорання $\epsilon$ проблемою, що потребує медичної уваги. Згідно з визначенням ВООЗ (2001), «синдром вигорання (burnout syndrome) - це фізичне, емоційне або мотиваційне виснаження, що характеризується порушенням продуктивності в роботі та втомою, безсонням, підвищеною схильністю до соматичних захворювань, а також вживанням алкоголю або інших психоактивних речовин з метою отримати тимчасове полегшення, що має тенденцію до розвитку фізіологічної залежності та (у багатьох випадках) суїцидальної поведінки [2]. Цей синдром звичайно розцінюється як стрес-реакція у відповідь на безжалісні виробничі та емоційні вимоги, що відбуваються через надмірну відданість людини своїй роботі з супутньою цьому зневагою до сімейного життя або відпочинку» [16]. Основною причиною розвитку синдрому емоційного вигорання вважають психологічну перевтому людини за наявності тривалого впливу професійного стресу. Однією з професій, у представників якої синдром емоційного вигорання трапляється в майже 70 \% фахівців, $є$ медична професія. Варто відзначити, що саме в цієї категорії працівників спостерігають досить високу частоту депресивних порушень, а близько третини медичних працівників регулярно застосовують медикаментозні засоби для корекції емоційного рівня напруження та тривожності [5, 13].

Високу частоту синдрому емоційного вигорання серед медичних працівників частково пояснюють інтенсивним тривалим психологічним перевантаженням, специфікою пацієнтів, фінансовою нестабільністю сучасної сфери медичної допомоги. Зовнішніми передумовами розвитку емоційного вигорання $\epsilon$ наявність хронічної напруженої психоемоційної діяльності, дестабілізуюча організація роботи, підвищений рівень відповідальності, несприятлива психологічна сфера професійної діяльності та складний психологічний контингент пацієнтів. Внутрішніми чинниками розвитку синдрому емоційного вигорання $\epsilon$ інтенсивність та стиль спілкування людини, відповідність ії темпераменту роботі, спрямованість до екстра- чи інтравертованості [4]. Схильні до розвитку синдрому емоційного вигорання люди є емоційно холодними або виражено емоційно лабільними, які не здатні до чіткого, злагодженого та рівномірного розподілу свого робочого часу та професійних дій. Окремим чинником розвитку синдрому $є$ робота з психологічно тяжким контингентом хворих, зокрема онкохворими, та постійний безпосередній контакт із пацієнтами, які потребують термінової допомоги чи перебувають у критично тяжкому стані [6].

Виділяють декілька груп ключових симптомів, характерних для емоційного вигорання: фізичні (втомлюваність, безсоння, погіршення самопочуття, прояви вегетативної дисфункції), емоційні (песимізм, цинізм, байдужість, депресія, почуття самотності й провини), поведінкові (імпульсивна поведінка, постійне бажання відпочити, байдужість до їжі, виправдання чи потяг до вживання тютюну, алкоголю), інтелектуальні (втрата інтересу до роботи, формальне виконання роботи, байдужість до нових ідей) та соціальні симптоми (втрата інтересу до дозвілля, соціальних контактів і соціальної активності, відчуття ізоляції, відчуття нестачі підтримки з боку родини та друзів) [10, 12].

У дебюті розвитку синдром емоційного вигорання проявляється почуттям байдужості до хворих, підвищеною втомлюваністю, погіршенням професійних якостей, уваги та пам'яті, негативним ставленням до колег та хворих, невпевненістю в собі. Надалі медпрацівник може ставати відчуженим, ригідним у мисленні, почати уникати колег та пацієнтів, фізично і духовно дистанціюючись від них. Необхідно відзначити, що наслідки синдрому емоційного вигорання можуть проявлятися у психосоматичних порушеннях, психологічній зміні особистості та вираженій деперсоналізації, навіть до суїциду [3].

Якщо медичний працівник протягом довгого часу займається професійною діяльністю, не відчуваючи свого зв'язку з нею, тобто не бачить внутрішньої цінності, не може їй дійсно віддатися, то неминуче виникає внутрішнє спустошення, тому що не відбувається діалогічного обміну, в якому людина не тільки віддає, але й отримує [11]. Як наслідок, розлад набуває характеру депресії. Емоційне вигорання - це вид депресії, що виникає без травматизації й органічних порушень, а тільки лише через поступову втрату життєвих цінностей [14]. На думку багатьох дослідників, емоційне вигорання більшою мірою властиве представникам медичної професії. Їхня робота пов'язана з інтенсивним, тісним спілкуванням з людьми та емоційним перенапруженням. Зокрема, для медичних сестер притаманні такі якості, як комунікабельність, емпатія (проникнення у внутрішній світ іншої людини за рахунок причетності її переживань), пригнічення особистих прагнень заради ініціатив та індивідуальних особливостей клієнтів, а також саме їм притаманний гуманізм і милосердя. Праця представників медичних 
професій супроводжується досить інтенсивним та тривалим спілкуванням (особливо в разі надання допомоги у вирішенні проблем і труднощів пацієнта) й вимагає великих психологічних і фізіологічних витрат, а отже, рано чи пізно призводить до перевантажень, емоційного, фізичного і розумового виснаження [17]. Медичні сестри можуть переносити значний стрес без підвищеного ризику розвитку психічного або соматичного захворювання, якщо вони отримують адекватну підтримку. На практиці це означає повагу і прийняття людської природи медичного працівника і таким його життя за межами роботи, щоб він міг задовольняти власні потреби поряд із потребами пацієнтів, а також створення матеріальної зацікавленості в результатах праці.

Виробниче навантаження медичних сестер, цілодобовий режим роботи з обов'язковими чергуваннями, очікування ускладнень в стані хворих вимагають високої функціональної активності організму медичної сестри і можуть бути кваліфіковані як провідні патогенні професійні чинники. Крім того, обтяжуючий вплив на здоров'я працюючих надає контакт із вмираючими хворими, коли медичний працівник не бачить позитивних результатів своїх зусиль з порятунку хворого і нерідко відчуває власне безсилля. У результаті розвиваються церебральні порушення в формі неврозу, сомато-вісцеральні порушення у вигляді гіпертензії, стенокардії, виразкових уражень шлунковокишкового тракту [14]. Професійна діяльність нерідко має негативний вплив на особистість, призводить до депресії. Чим більше виробниче навантаження, тим менше медичний працівник відчуває задоволення від самого процесу роботи. Перевищення нормативного числа пацієнтів, великий обсяг «паперової» роботи, низька технічна оснащеність робочого місця і постійний дефіцит лікарських засобів також сприяють проявам втоми і нервозності. 3 ергономічних чинників медсестри часто відзначають напруження зору, перевантаження опорно-рухового апарату [13].

Низька оплата праці медичних сестер за умов розвитку ринкової економіки змушує працювати, часто нехтуючи часом, передбаченим на відпочинок для відновлення фізичного та емоційного балансу організму. Величезна відповідальність за результат своєї діяльності - життя пацієнта - призводить до перенапруження окремих органів і систем, виникнення захворювань [9].

Медична сестра перебуває в рамках медико-економічних стандартів, вимог до обсягу медичної до- помоги та діагностичних втручань, які вона повинна виконати стосовно пацієнта. Однак фінансування охорони здоров'я не відповідає цьому обсягу. Медичний персонал схильний до високого професійного ризику зараження парентеральними вірусними гепатитами, ВІЛ-інфекцією, туберкульозом та іншими загрожуючими життю захворюваннями [11]. Медична сестра перебуває в постійному контакті з лікарськими і дезінфікуючими засобами, що створює небезпеку алергічних і токсико-хімічних уражень. Вплив іонізуючих і неіонізуючих випромінювань (радіація, ультразвук, лазерне) $\epsilon$ потенційною причиною виникнення катаракти, новоутворень. Інтенсивна робота в несприятливих умовах праці та при високій зношеності обладнання зумовила високі показники виявлення і зростання професійної захворюваності серед медичних працівників.

Поряд із прагненням знижувати емоційне навантаження в ситуації професійного стресу часто спостерігають зворотний варіант, пов'язаний з «трудоголізмом» - прагненням компенсувати відчуття своєї недостатньої професійної успішності ще більшою ретельністю і напруженістю у роботі, нерідко за рахунок сімейних, дружніх та інших значущих для людини відносин. Вносячи професійні питання в сім'ю, вони ризикують зіпсувати особисті взаємини. Вони не в змозі виконувати інші обов'язки і отримувати від цього задоволення. Образ батька, який не здатний відключатися від роботи і недоступний для своїх дітей, залишається сумним стереотипом у нашому соціумі [14].

Багато фахівців, перебуваючи в стані емоційного вигорання, щиро переконані, що жорсткі соціальні стандарти медичної професії накладають обмеження не тільки на стиль поведінки, але і на почуття («я не маю права відчувати злість, роздратування, страх, провину»). І це створює відчуження від самого себе. Якщо ж при цьому медична сестра несвідомо прагне грати роль «батька» або «рятівника», що відповідає за все, - це прямий шлях до професійного стресу [8].

Поведінка медичних сестер, які працюють в екстремальних умовах, характеризується двома крайнощами - відстороненням і повним «злиттям» з пацієнтом. При дуже маленькій просторовій і емоційній дистанції між індивідуумами фахівець «заражається» його станом, як би втягується в нього, де розчиняється і втрачає «почуття себе». Це один варіант виникнення синдрому емоційного вигорання. Інший варіант - людина просто не підпускає інших до себе. 
На спілкування вона йде, підганяючи себе, словом «повинен». У цій групі перебувають люди, які компенсують недостатність особистого життя. Наприклад, у людини немає своїх дітей або не складаються стосунки з ними, тому вона компенсує невдачі приватного життя у відносинах з оточуючими. Вигорання - не від непосильної включеності в трудову діяльність, а скоріше від поганого знання себе, неповного дозволу особистих проблем, які не дають можливості відчути в спілкуванні з людьми легкість і радість [15].

$€$ організаційні та економічні обставини, які посилюють деформований підхід до хворого. При плануванні завжди більше уваги приділяють придбанню діагностичної апаратури і лабораторного обладнання, аніж перебудові лікарняних відділень відповідно до вимог лікувально-охоронного режиму. Необхідно пам'ятати, що пацієнт потребує створення хоча 6 мінімальних персональних умов. Часто медичні сестри не мають кімнати для перепочинку на робочому місці. Необхідно стежити, щоб підсвідома і безконтрольна деформація не стала одним із чинників ятрогенного ураження медичних працівників. Необхідною і базовою частиною профілактики виникнення синдрому емоційного вигорання є особистісне психологічне навчання медичних сестер [7]. Під цим розуміють не тільки теоретичне навчання основам психології (хоча і воно не втрачає своєї значущості), а й практичне, спрямоване на розвиток стресостійкості професіонала [6].

Ще один важливий аспект цієї проблеми: емоційне вигорання, як правило, є наслідком неконструктивного спілкування з колегами і керівництвом. Позитивний клімат всередині колективу, почуття достатньої емоційної підтримки колег та адміністрації - це потужний ресурс попередження і усунення професійного стресу. Відчуття захищеності в колективі, наявність надійної опори серед колег, можливість довірчо обговорювати питання, пов'язані зі стресом на роботі, дозволяють знизити напруженість, тривогу, а також часті агресивні прояви. Керівники, приймаючи на роботу співробітників, повинні розглядати персонал як свій найцінніший ресурс і піклуватися про його збереження.

Висновки. Професійне вигорання медичних сестер являє собою психічне, емоційне та фізичне виснаження, що розвивається внаслідок довготривалого професійного стресу. Специфіка професійної діяльності медичних сестер зумовлює необхідність вироблення наявності в персоналу певних психологічних і фізичних особливостей, які забезпечать професійну успішність працівників та можливість протистояти екстремальним чинникам на робочому місці.

\section{СПИСОК ЛІТЕРАТУРИ}

1. Водопьянова Н. Е. Синдром психического выгорания в коммуникативных профессиях // Психология здоровья / Н. Е. Водопьянова ; под ред. Г. С. Никифорова. - СПб. : Издательство СПб ГУ, 2000. - С. 443-463.

2. Психическое здоровье: новое понимание, новая надежда : доклад о состоянии здравоохранения в мире, 2001 г. // ВОЗ. - Женева : ВОЗ, 2001. - 178 с.

3. Матвієнко О. Культура здоров'я та синдром психоемоційного «вигорання»: стратегія і тактика подолання [Електронний ресурс] / О. Матвієнко, М. Пересадін, Є. Андросов. - Режим доступу : http://www.personal.in.ua/.

4. Матулене Г. О социальной адаптации к деятельности (обзор зарубежной литературы) / Г. Матулене // Психологический журнал. - 2002. - Т. 23, № 5. - С. 108-112.

5. Орел В. Е. Феномен «выгорания» В зарубежной психологии: эмпирические исследования и перспективы / В. Е. Орел // Психологический журнал. - 2001. - Т. 22, № 1. - С. 90-101.

6. Платонов Ю. П. Психология конфликтного поведения / Ю. П. Платонов. - СПб. : Реч, 2009. - 544 с.

7. Райкова Е. Ю. Терапия и профилактика профессионального выгорания у представителей помогающих профессий [Текст] / Е. Ю. Райкова // Молодой ученый. 2011. - Т. 2, № 5. - С. 92-97.

8. Сандомирский М. Е. Психосоматика и телесная психотерапия : практическое руководство / М. Е. Сандомирский. - М. : Независимая фирма «Класс», 2005. - 592 с.

9. Самикіна Н. Синдром вигоряння у працівників пенітенціарної системи / Н. Самикіна, В. Сулицький // Соціальна психологія. - 2004. - № 4 (6). - С. 43-48.

10. Сидоров П. И. Синдром эмоционального выгорания (лекция) / П. И. Сидоров // Международный неврологический журнал. - 2007. - № 1 (11). - С. 129-140.

11. Трунов Д. И снова о «профессиональной деформации» / Д. Трунов // Психологическая газета. - 2004. № 6. - С. 32-34. 
12. Чижма Д. М. Аналіз теоретичних підходів до проблеми саморегуляції особистості / Д. М. Чижма // Актуальні проблеми психології : зб. наук. праць Інституту психології ім. Г. С. Костюка АПН України. Т. Х, вип. 4 ; за ред. С. Д. Максименка. - К., 2008. - С. 333-340.

13. Чумакова Г. А. Синдром выгорания медицинских работников / Г. А. Чумакова, И. Е. Бабушкин, Л. А. Бобровская. - М. : Владос, 2003. - 78 с.

14. Hospital nurse staffing and patient mortality, nurse burnout and job dissatisfaction / L. H. Aiken, S. P. Clarke, D. M. Sloane [et al.] // JAMA. - 2002. - Vol. 288 (161).
15. Green D. E. The three-factor structure of the Maslach Burnout Inventory: A multicultural, multinational confirmatory study / D. E. Green, F. H. Walkey, A. J. Taylor // Journal of Social Behavior and Personality. - 1991. Vol. 6 (3). - P. 453-472.

16. Maslach C. Burnout research in the social services: a critique / C. Maslach // Journal of Social Service Research. 1987. - No. 10. - P. 95-105.

17. Schaufeli W. B. The burnout companion to study \& practice; a critical analysis /W. B. Schaufeli, D. Enzmann. - L. : Taylor and Francis, 1998. - P. 77-85.

Отримано 26.03.20 